\title{
Influence of Electronic Word of Mouth (eWOM) and Relationship Marketing on Brand Resonance: A Mediation Analysis
}

\author{
Sufyan Habib ${ }^{1}$, Nawaf N. Hamadneh ${ }^{2, *}$ (D) and Mohammed Arshad Khan ${ }^{3}[$ \\ 1 Department of Business Administration, College of Administration and Finance, Saudi Electronic University, \\ Riyadh 11673, Saudi Arabia; s.habib@seu.edu.sa \\ 2 Department of Basic Sciences, College of Science and Theoretical Studies, Saudi Electronic University, \\ Riyadh 11673, Saudi Arabia \\ 3 Department of Accountancy, College of Administrative and Financial Sciences, Saudi Electronic University, \\ Riyadh 11673, Saudi Arabia; m.akhan@seu.edu.sa \\ * Correspondence: nhamadneh@seu.edu.sa
}

\section{check for} updates

Citation: Habib, S.; Hamadneh, N.N.; Khan, M.A. Influence of Electronic Word of Mouth (eWOM) and Relationship Marketing on Brand Resonance: A Mediation Analysis. Sustainability 2021, 13, 6833. https:// doi.org/10.3390/su13126833

Academic Editors:

María-Ángeles Revilla-Camacho, Dolores Garzón, Carlos

J. Rodríguez-Rad and Marc A. Rosen

Received: 20 April 2021

Accepted: 1 June 2021

Published: 17 June 2021

Publisher's Note: MDPI stays neutral with regard to jurisdictional claims in published maps and institutional affiliations.

Copyright: (c) 2021 by the authors. Licensee MDPI, Basel, Switzerland. This article is an open access article distributed under the terms and conditions of the Creative Commons Attribution (CC BY) license (https:// creativecommons.org/licenses/by/ $4.0 /)$.

\begin{abstract}
This study investigates how electronic work of mouth (eWOM) mediates the relationship between marketing relations and brand resonance. Based on the information obtained from 473 customers using an online questionnaire, this study analyses the relationship between eWOM, relationship marketing practices and the brand resonance of lifestyle products in an Indian context. The results from the multiple regression analysis indicate that the proposed hypotheses are valid, that relationship marketing significantly affects brand resonance, and that eWOM significantly mediates the relationship between the relationship marketing and brand resonance of branded apparel. The findings suggest that personalized attention and tangible rewards are effective relationship marketing strategies, and that these relationship-marketing practices—in association with eWOM-build up the strong brand resonance of branded apparel. The present study recommends that marketers should place emphasis on effective online and offline relationship marketing strategies, and should design appropriate eWOM strategies to enhance brand loyalty, brand attachment, brand community and brand engagement. Some of the managerial implications and the future scope of study based on the empirical findings are also highlighted in the present research work.
\end{abstract}

Keywords: brand resonance; relationship marketing; electronic word of mouth (eWOM); lifestyle products; regression analysis

\section{Introduction}

Business organizations operate in a highly competitive environment as a consequence of a number of factors, such as the emergence of new markets, the rise in market demand, the increasing expectations of modern customers, the quality of services and products, value conscious customers, the rise in operational costs and declining profitability in addition to the inflation [1]. Organizations can only survive by employing strategic and competitive measures towards attaining good positioning, a sustainable competitive advantage, differentiation and value creation [2]. Several researchers, including [3-5], have advocated that two important strategic factors - relationship marketing and branding-are critical for competing effectively and fostering differentiation, as well as creating firm value and customer value. Relationship marketing and brand resonance have become part of the necessary requirement for modern organizations to operate successfully and to create competitive advantages in a dynamic environment. [2,4] posit that relationship marketing enables marketers to build long-term relationship with customers, help brands understand their customers beyond a single interaction, and explain strategic variables associated with marketing efforts. In addition to relationship marketing, effective eWOM 
is another strategic measure that enhances customer awareness, builds purchase intention and influences final purchase.

Effective relationship marketing and eWOM help business organizations to reduce the risks associated with a competitive business landscape. A strong brand mitigates risk, aids in the decision-making process and differentiates the brand from other offerings [6-8]. The customer-based brand equity (CBBE) pyramid or brand resonance model proposed by Keller [9] provides a sequential structure for building a strong brand. As a top element of the CBBE pyramid, brand resonance is the extent to which a consumer develops strong behavioral, psychological and social bonds with the brands [10]. Brand resonance plays a crucial role in managing the customer relationship, developing sustainable brand equity, creating loyalty and building an emotional association with the brand [11,12]. Brand Resonance is a dominant state of the psychological relationship that every organization would like to establish with its customers. It is the way a by which a customer relates to a brand. This study is concerned with examining the association between relationship marketing, eWOM and brand resonance for lifestyle products.

In recent years, marketing professionals have focused on managing customer relationships and their marketing as a theoretical lens for understanding consumer-brand interactions [13,14]. Many studies have introduced the use of the relationship metaphor to enhance the understanding of the various dimensions of brand resonance. According to a review of the branding literature [15-17], the construct of brand resonance defines the stepwise development of the brand relationship. Even though previous studies have investigated brand resonance in consumer research, the role of eWOM communication in strengthening relationship marketing for better brand resonance remains unknown. The research question is whether relationship marketing has an effect on the brand resonance of clothing products. Moreover, does effective eWOM communication mediate the relationship between relationship marketing components and apparel brand respondents? The study of this is more contemporary and justifiable in an Indian context, as India is considered to be the second-largest emerging market for consumer goods due to its favorable demographical and socio-economical advantage, rising disposable income, effective brand promotions, high demand for lifestyle products, increasing consumption, and spending on lifestyle products and luxury items [18]. The Indian apparel market has witnessed a huge influx of international brands in the last few years. The findings of the present work will be beneficial for marketers in designing suitable relationship and eWOM strategies to influence brand resonance among consumers in this emerging economy.

\section{Literature Review and Hypothesis Development}

\subsection{Relationship Marketing and Brand Resonance}

Relationship marketing is a value creation process intended to retain existing customers, develop powerful relationships to affect their repurchase decisions, and generate brand advocacy [2]. It requires generating, maintaining and improving the strong relationship with customers and other stakeholders within and outside an enterprise. According to [19], an improved capability to target profitable consumers, a unified assistance across channels, improved marketing force efficiency and effectiveness, improved pricing, customized products and services, enhanced consumer service efficiency and effectiveness, and individualized marketing messages are the seven core benefits of relationship marketing. With the regular usage of the marketing methods at the disposal of business owners, relationship marketing is playing a greater role as they look for ways to differentiate themselves and create long lasting, meaningful brand and customer experiences.

Keller [11] defined brand resonance as the strength or extent of the psychological connection that customers have with the brand and the degree of operation generated by this loyalty. According to Keller, brand resonance has four dimensions, which comprise brand loyalty, brand attachment, brand community and brand engagement. Tracking out the linkage between relationship marketing dimensions and brand resonance, brand attachment is directly influenced by the core factors of relationship marketing, which in- 
clude trust and satisfaction [20]. The research of [21] validated the significant and positive relationship between conflict handling and brand loyalty through trust and relationship quality. When the service providers deal with the conflicts of customers effectively and effeciently, they develop a loyalty towards the enterprise or the brand. Beyond conflict handling, empathy also generates the loyalty of the customers, as per the research conducted by [22]. With such great advantages, brand resonance can be used by the organization to gain a competitive advantage [23]. Many organizations seek to enhance brand resonance dimensions by using relationship marketing. Relationship marketing has more significance to service enterprises compared to product enterprises. The above arguments lead to the following hypothesis:

Hypothesis 1 (H1). Relationship marketing has a positive effect on brand resonance towards branded apparels.

\subsection{Relationship Marketing and eWOM}

Relationship marketing involves the creation of easy two-way communication between customers and the business, tracking customer activities and providing tailored information to customers based on those activities. EWOM has made it easy for marketers to enhance their relationship with customers, establish strong communication, and convince customers in favour of their products. EWOM is any favourable or unfavourable communication made by prospective, existing or previous customers about a brand or organization, which is capable of reaching to millions of individuals and organizations through the internet [24]. EWOM communication-usually attributed to written words, indirect interactions, anonymity and a wide scope-offers higher reliability and better understanding and significance to shoppers than commercial information sources on the internet created by marketers [25]. EWOM brings a significant change in the knowledge, attitude and behavior of the audience. EWOM messages effectively minimize the chances of risk and ambiguity while making the purchase decision, and thus influences consumers' subsequent intention to purchase [18,26-28]. Spending on marketing and advertising campaigns to acquire new customers and retain existing customers can be expensive. Relationship marketing influences customers to become brand ambassadors and effectively spread word of mouth digitally for the brand, which consequently drives sales. These arguments lead to the following hypothesis:

Hypothesis 2 (H2). Relationship marketing has a positive effect on eWOM for branded apparels.

\subsection{Electronic Word of Mouth (eWOM) and Brand Resonance}

EWOM plays an important role in improving brand recognition and creating positive brand relationships. EWOM is recognized as an effective tool for building brand awareness, creating hype in the marketplace, influencing purchase decisions and developing brand loyalty [18]. Examining the effect of eWOM on brand image and purchase intention, [18,29,30] found the strong influence of eWOM on brand image and purchase intention. Several studies have examined the relationship between the individual elements of brand resonance (i.e., brand loyalty, brand attachment, brand community and brand engagement) and eWOM. In the social media environment, loyal consumers usually tend to be ambassadors of the brand for other consumers [31]. Several researchers have attested that positive eWOM creates and strengthens customers' loyalty towards brands [18,29,30,32]. Regarding brand attachment, the studies of [33-36] found that brand attachment develops emotional bonds with customers and motivates them to generate positive WOM.

Laroche et al. [37] found that online brand communities have a positive effect on the relationship between the customer-brand and customer-organization. This results in a positive effect on trust, brand loyalty and recommendations. Qiao et al. [38] found that identification with an online community motivates community users to participate and help others by generating eWOM. Positive interactions, experience and engagement with 
online brand communities develop positive brand evaluation and customer satisfaction, and improve brand loyalty. The occurrence of eWOM on social networks is positively associated with the intensity of the relationship, trust and interpersonal influence, and is negatively associated with affinity [39]. The previous works of [40-42] advocated the positive relationship between eWOM and brand engagement. Engaged consumers are less prone to switch their preferences towards a competitors' brand, show high brand loyalty and generate positive recommendations [37]. Al-Dmour [43] showed that eWOM has a notable positive effect on purchase intention and brand image; the brand image has a notable positive effect on purchase intention, and eWOM has a complete indirect effect on purchase intention through the brand image as a mediating factor. The author's recommendation is that firms should focus on eWOM to stimulate a brand image. Consequently, we propose the following hypotheses:

Hypothesis 3 (H3). EWOM has a positive effect on the brand resonance of branded apparels.

Hypothesis 4 (H4). EWOM mediates the relationship between relationship marketing and the brand resonance of branded apparels.

The conceptual framework of the study, as shown in Figure 1, proposes the hypothesized relationship among relationship marketing, brand resonance and eWOM.

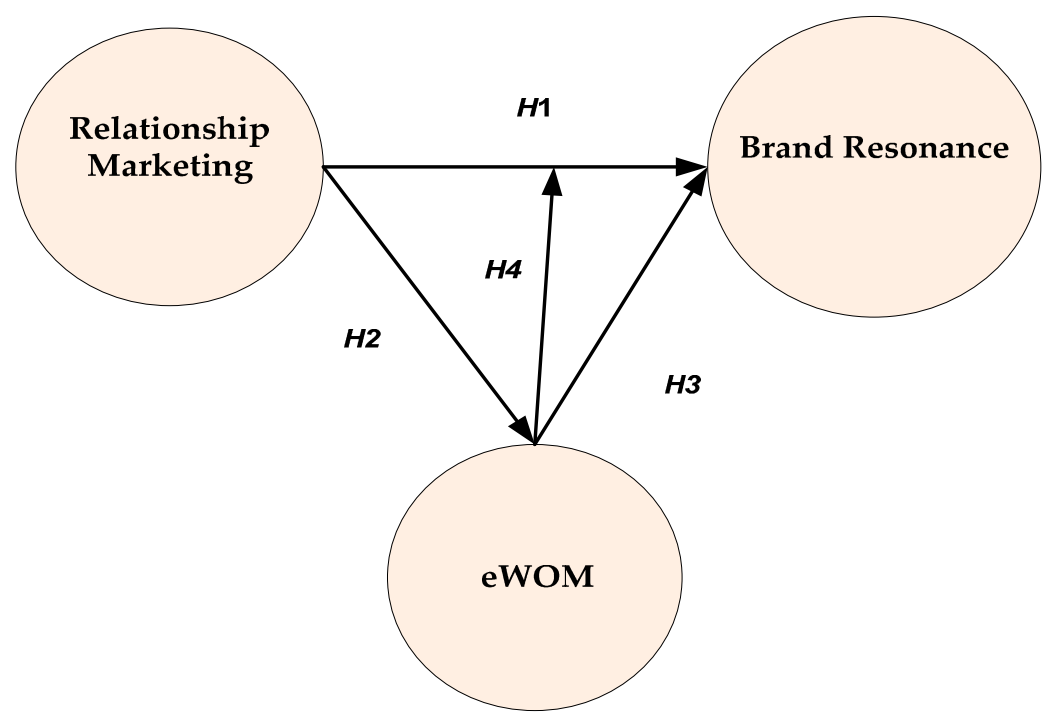

Figure 1. The conceptual framework.

\section{Research Methodology}

Branded apparels were chosen for this study as lifestyle products. The data for this study were collected through responses received from Indian consumers using an online questionnaire generated through Google document for three months, from June to August 2020. The customers were requested to reply by email. The survey questionnaire consisted of three sections. The first part consisted of questions related to the demographic profile of the respondents and the motivation of purchasing branded apparels. The second part of questionnaire contained attributes related to relationship marketing practices, EWOM effectiveness and brand resonance. Relationship marketing was measured by interpersonal communication, direct mail, tangible rewards, preferential treatment, customization methods and the individualization attention, as adopted from the previous study of [44]. EWOM was measured according to seven attributes taken from the previous works of $[18,33]$. Brand resonance was measured by developing four constructs namely Behavioural Loyalty, Affective Attachment, Sense of Continuity and Affective Engagement, which were taken from previous studies [45-48]. Participants were instructed to indicate their preferences 
according to their level of agreement with the given attributes in a five-point Likert-scale (where 5 designated strongly agree and 1 designated strongly disagree).

A panel of experts and academicians of the marketing domain vetted the initial questionnaire by judging the content's validity, the clarity of its items' meanings and the linkages of the identified variables with the research objectives. For reliability, the questionnaire was pilot tested using 55 respondents, representing $13 \%$ of the total proposed sample, who were considered the representatives of the study population. The value of Cronbach's alpha was found to be 0.983 , which suggested the acceptable level of reliability of the questionnaire. The consumers were invited to participate in the study via email and by posting invitations to well-known sites using snowball sampling, in which potential respondents were asked to complete the questionnaire and forward it to someone known to them. Initially, the questionnaire was mailed to 1500 respondents. The researchers received 498 responses and, after editing, 473 respondents were found fit to be used in this study, excluding 25 responses that were incomplete or insincerely answered. The sample size was calculated for an infinite population keeping a level of confidence of $95 \%$ and a margin of error of 0.05 to calculate that the sample size. The data thus received was systematically arranged, tabulated and analyzed through SPSS software. Some of the statistical techniques like descriptive statistics, regression analysis and the Sobel test for mediation analysis were used to draw the inferences.

\section{Results}

The demographic profiles of the respondents presented in Table 1 indicate that $52.6 \%$ of respondents were in the age group of $19-25$ years. In total, $25.4 \%$ of the respondents were in the age group of $26-35$ years, $10.8 \%$ of respondents were in the age group of $36-45$ years, and $2.1 \%$ of respondents were in the age group of $46-55$ years. The remaining $9.1 \%$ of respondents were above 55 years. The majority of the respondent $(69.6 \%)$ were in the male category, and more than half $(57.3 \%)$ of the respondents were unmarried. Regarding education level, $39.1 \%$ of the respondents surveyed were graduates, $19.9 \%$ were postgraduates, and $25.8 \%$ of respondents were below graduation level. In total, $15.2 \%$ of the respondents had qualifications like technical degrees or diploma certificates. Regarding the monthly income level, $31.9 \%$ of the respondents were earning INR 20,001-40,000, $29.8 \%$ were earning INR $40,001-60,000$ and $20.5 \%$ were receiving INR $60,001-80,000$. The remaining $17.8 \%$ of respondents had a monthly income in the range of INR 80,001-100,000. Students dominated the sample with $44.6 \%$, followed by salaried individuals $(32.1 \%)$ and business professionals (12.3\%).

Table 1. Demographic profile of the respondents $(n=473)$.

\begin{tabular}{|c|c|c|c|c|c|c|c|}
\hline \multicolumn{2}{|c|}{ Demographic Characteristics } & \multirow{2}{*}{$\frac{F}{249}$} & \multirow{2}{*}{$\begin{array}{c}\% \\
52.6\end{array}$} & \multicolumn{2}{|c|}{ Demographic Characteristics } & \multirow{2}{*}{$\begin{array}{c}\mathbf{F} \\
211\end{array}$} & \multirow{2}{*}{$\begin{array}{c}\% \\
44.6\end{array}$} \\
\hline \multirow{5}{*}{ Age } & 19-25 Years & & & \multirow{5}{*}{ Occupation } & Student & & \\
\hline & 26-35 Years & 120 & 25.4 & & Business & 58 & 12.3 \\
\hline & $36-45$ Years & 51 & 10.8 & & Salaried & 152 & 32.1 \\
\hline & 46-55 Years & 10 & 2.1 & & Professionals & 34 & 7.2 \\
\hline & Above 55 Years & 43 & 9.1 & & Housewives & 18 & 3.8 \\
\hline \multirow{2}{*}{ Gender } & Male & 329 & 69.6 & \multirow{2}{*}{$\begin{array}{c}\text { Marital } \\
\text { Status }\end{array}$} & Unmarried & 271 & 57.3 \\
\hline & Female & 144 & 30.4 & & Married & 202 & 42.7 \\
\hline \multirow{4}{*}{ Education } & Less than Graduation & 122 & 25.8 & \multirow{4}{*}{$\begin{array}{l}\text { Income } \\
\text { (in INR) * }\end{array}$} & $20001-40000$ & 151 & 31.9 \\
\hline & Graduate & 185 & 39.1 & & $40001-60000$ & 141 & 29.8 \\
\hline & Post Graduate & 94 & 19.9 & & 60001-Rs80000 & 97 & 20.5 \\
\hline & $\begin{array}{c}\text { Technical } \\
\text { degree/Diploma }\end{array}$ & 72 & 15.2 & & 80001-100000 & 84 & 17.8 \\
\hline
\end{tabular}

*(1 USD = 74.04 INR, as on 7 December 2020). 
Table 2 summarizes the customer-perceived reasons of preferring branded apparels. The important reasons in the choice of branded apparels were rising income (81.2\%), increasing awareness $(60.9 \%)$, the easy availability of the product $(57.9 \%)$, being comfortable in its use $(32.3 \%)$, as a means of self-expression $(49.7 \%)$, superior design and perfect fit $(50.3 \%)$ and better product quality $(28.8 \%)$.

Table 2. Reasons of moving towards branded apparels.

\begin{tabular}{cccc}
\hline Reasons & \multicolumn{2}{c}{ Responses } & $\begin{array}{c}\text { Percent of } \\
\text { Cases }\end{array}$ \\
\cline { 2 - 3 } & $n$ & Percent & $81.2 \%$ \\
Rising Income & 384 & $22.5 \%$ & $60.9 \%$ \\
Increasing awareness & 288 & $16.9 \%$ & $57.9 \%$ \\
Easy availability of product & 274 & $16.0 \%$ & $32.3 \%$ \\
Comfortable in its uses & 153 & $9.0 \%$ & $49.7 \%$ \\
A means of Self Expression & 235 & $13.8 \%$ & $50.3 \%$ \\
Superior design and Perfect fit & 238 & $13.9 \%$ & $28.8 \%$ \\
Better Product Quality & 136 & $8.0 \%$ & $361.1 \%$ \\
Total & 1708 & $100.0 \%$ & \\
\hline
\end{tabular}

The data summarized in Table 3 for various factors of relationship marketing reveal that the individualization attention factor secured the highest mean (3.75). It is followed by tangible rewards (3.74), preferential treatment (3.64), customization methods (3.58), interpersonal communication (3.58) and direct mail (3.54). The attribute "The retailer provides individual attention in offering the brand according to their measurement" was ranked highest, with mean $\mathrm{m}=3.86$ and standard deviation $=1.018$. It was followed by the attributes "The retailer guarantees that, if I am not satisfied, I can return the product" with mean (3.8245) and SD (1.092). The combined mean of the relationship marketing factor was scored at 3.64 with standard deviation 0.585 . The reliability $(\alpha)$ value of relationship marketing was found to be 0.802 , which is sufficient for further statistical analysis.

Table 4 indicates the descriptive statistics related to eWOM in enhancing the brand resonance of branded apparel products, as rated by customers. From Table 4, it can be observed that the eWOM attributes "I am ready to pay extra premium for the brand that is recommended through eWOM" scored the highest mean of 4.22 , with a standard deviation of 0.743 . It is followed by attributes "eWOM bridges the relationship with marketer and consumer, and enhances brand loyalty", with a mean of 4.11. The attributes "eWOM is helpful in establishing the strong relationship and bonding with Brand" scored the lowest mean of 3.89. The combined mean and standard deviation of eWOM effectiveness were found to be 4.01 and 0.605 , respectively. The reliability $(\alpha)$ value of eWOM was found to be 0.933 , which is sufficient for further statistical analysis.

The data presented in Table 5 refer to the descriptive statistics of various factors influencing brand resonance. Affective engagement $(\mathrm{m}=4.31, \mathrm{SD}=0.676)$ scored the highest weightage in enhancing the brand resonance of branded apparels. It was followed by the sense of continuity $(\mathrm{m}=4.24, \mathrm{SD}=0.638)$, affective attachment $(\mathrm{m}=4.06, \mathrm{SD}=0.635)$ and behavioral loyalty $(\mathrm{m}=3.83, \mathrm{SD}=0.593)$. The attribute "I prefer to watch a report of this brand closely in different media platforms" scored the highest mean of 4.35 and standard deviation of 0.679 . It is followed by the attribute "I really like to talk to others about this fashion brand (mean $=4.33, \mathrm{SD}=0.715$ ). The combined mean of brand resonance was found to be 4.108 . The reliability $(\alpha)$ value of brand resonance was found to be 0.959 , which is sufficient for further statistical analysis. 
Table 3. Relationship marketing practices: descriptive statistics $(n=473)$.

\begin{tabular}{|c|c|c|}
\hline Variables & Mean & SD \\
\hline Relationship Marketing $(\alpha=0.802)$ & 3.64 & 0.585 \\
\hline Interpersonal communication $(\alpha=0.642)$ & 3.58 & 0.876 \\
\hline The management put time and effort to know its regular customers personally. & 3.76 & 1.037 \\
\hline This shop also carries out friendly discussions with it regular customers. & 3.32 & 1.149 \\
\hline This store frequently asks about the personal wellbeing of regular customers. & 3.67 & 1.249 \\
\hline Direct mail $(\alpha=0.744)$ & 3.54 & 0.867 \\
\hline $\begin{array}{l}\text { I receive notification through the mail informing me when the new brand are } \\
\text { on sale. }\end{array}$ & 3.53 & 1.135 \\
\hline This organization regularly sends mail to its regular customer. & 3.59 & 1.234 \\
\hline This organized store keeps its customer updated by sending regular message. & 3.67 & 1.216 \\
\hline $\begin{array}{l}\text { The management keeps their regular customers informed through brochures } \\
\text { about product features and important benefits. }\end{array}$ & 3.38 & 1.014 \\
\hline Tangible Rewards $(\alpha=0.701)$ & 3.74 & 0.818 \\
\hline $\begin{array}{c}\text { Organization encourage its customer with incentives for habitual purchase of } \\
\text { products. }\end{array}$ & 3.80 & 0.929 \\
\hline $\begin{array}{c}\text { This store offers something extra to regular customers because they keep } \\
\text { shopping there. }\end{array}$ & 3.65 & 1.095 \\
\hline This department store gives customers frequent rewards for their loyalty. & 3.77 & 1.072 \\
\hline Preferential Treatment $(\alpha=0.722)$ & 3.64 & 0.809 \\
\hline This store puts more effort on regular customers than on non-regular clients. & 3.68 & 1.040 \\
\hline This store offers better customer service than non-regular customers & 3.72 & .927 \\
\hline This store does more for regular clients than it does for non-regular clients & 3.51 & 1.056 \\
\hline Customization Methods $(\alpha=0.768)$ & 3.58 & 0.780 \\
\hline I am getting personal attention when I go shopping at the supermarket. & 3.53 & 1.105 \\
\hline The store staff are paying attention to my opinions/concerns. & 3.44 & 1.237 \\
\hline The workers at the store seem to care about me as a customer. & 3.67 & 0.975 \\
\hline The shop staff seem to be genuinely concerned for my needs and me. & 3.58 & 1.073 \\
\hline The store staff are very friendly to me. & 3.67 & 1.007 \\
\hline Individualization attention $(\alpha=0.760)$ & 3.75 & 0.795 \\
\hline $\begin{array}{c}\text { Retailer provides individual attention in offering brand according to their } \\
\text { measurement. }\end{array}$ & 3.86 & 1.018 \\
\hline I receive discounts based on the amount I spend on each product. & 3.53 & 0.925 \\
\hline I receive discounts based on volume I purchase from the retailer. & 3.77 & 1.126 \\
\hline
\end{tabular}

Table 4. EWOM: descriptive statistics $(n=473)$.

\begin{tabular}{ccc}
\hline Variables. & Mean & SD \\
\hline $\begin{array}{c}\text { eWOM ( } \alpha=0.933) \\
\text { for me } \\
\text { Recommendation by eWOM in favor of branded apparels is useful }\end{array}$ & 4.01 & 0.605 \\
$\begin{array}{c}\text { Recommendation by eWOM in favor of branded apparels influence } \\
\text { my choice while shopping. }\end{array}$ & 3.82 & 1.092 \\
Recommendation by eWOM in favor of branded apparels increases \\
$\begin{array}{c}\text { my interest in brand } \\
\text { I will make a decision to make a purchase of branded apparels } \\
\text { based on recommendation I received from eWOM }\end{array}$ & 3.83 & 0.782 \\
$\begin{array}{c}\text { My loyalty towards brand is increased through eWOM. } \\
\text { eWOM is helpful in establishing the strong relationship and } \\
\text { bonding with Brand }\end{array}$ & 3.96 & 0.852 \\
$\begin{array}{c}\text { eWOM bridge the relationship with marketer and consumer and } \\
\text { enhance brand loyalty }\end{array}$ & 3.98 & 0.737 \\
$\begin{array}{c}\text { I have trust in favour of brand recommended through eWOM } \\
\text { I am ready to pay extra premium for the brand that is } \\
\text { recommended through eWOM }\end{array}$ & 4.11 & 0.736 \\
\hline
\end{tabular}


Table 5. Brand resonance: descriptive statistics $(n=473)$.

\begin{tabular}{|c|c|c|}
\hline Variables & Mean & SD \\
\hline Brand Resonance $(\alpha=0.959)$ & 4.11 & 0.600 \\
\hline Behavioural Loyalty $(\alpha=0.896)$ & 3.83 & 0.593 \\
\hline $\begin{array}{l}\text { Advertisement of this product help a lot in converting me from } \\
\text { evoked set to final choice set. }\end{array}$ & 4.08 & 0.693 \\
\hline I wish to continuing buying this fashion brand. & 3.87 & 0.763 \\
\hline I believe that I am committed to this brand of apparel. & 3.73 & 0.708 \\
\hline $\begin{array}{l}\text { This brand is going to be my first choice when considering fashion } \\
\text { brands in the future. }\end{array}$ & 3.85 & 0.739 \\
\hline In the future, I will be loyal to this fashion brand. & 3.83 & 0.670 \\
\hline Affective Attachment $(\alpha=0.914)$ & 4.06 & 0.635 \\
\hline I like to purchase this brand of apparel as much as I can. & 3.85 & 0.643 \\
\hline $\begin{array}{l}\text { I wish to pay higher price over other fashion brands for the items of } \\
\text { this brand. }\end{array}$ & 4.03 & 0.716 \\
\hline $\begin{array}{l}\text { I wish to continue to buy this fashion brand even if its prices are } \\
\text { going higher. }\end{array}$ & 4.10 & 0.746 \\
\hline I really love the fashion brand. & 4.05 & 0.707 \\
\hline $\begin{array}{l}\text { I feel attached to those people in community who wear clothes } \\
\text { from this fashion brand. }\end{array}$ & 4.06 & 0.678 \\
\hline Sense of Continuity $(\alpha=0.916)$ & 4.24 & 0.638 \\
\hline Many people wearing this apparel line look really close to me. & 4.12 & 0.652 \\
\hline I feel a strong relation with people who wear clothes of this brand. & 4.30 & 0.717 \\
\hline $\begin{array}{l}\text { I will indeed be entering in the societies created by other people } \\
\text { who are involved in this fashion company. }\end{array}$ & 4.30 & 0.698 \\
\hline Affective Engagement $(\alpha=0.954)$ & 4.31 & 0.676 \\
\hline I really like to talk to others about this fashion brand. & 4.33 & 0.715 \\
\hline $\begin{array}{c}\text { I prefer to watch report of this brand closely in different media } \\
\text { platforms }\end{array}$ & 4.35 & 0.679 \\
\hline $\begin{array}{l}\text { I am in the habit of constantly searching for details regarding this } \\
\text { apparel brands. }\end{array}$ & 4.24 & 0.723 \\
\hline
\end{tabular}

\section{Regression Analysis}

Regression analysis was carried out to measure the coefficients of the linear equation between relationship marketing, eWOM and brand resonance. Combined factor means were used in the analysis of the relationship marketing, eWOM and brand resonance constructs. Before performing the regression analysis, multicollinearity was tested to assess model fitness and whether multicollinearity is present in the model, which may affect our model with more than one predictor. Multicollinearity is characterised by extremely high intercorrelations or inter-associations between independent variables. As a result, it is regarded as a type of disturbance in the data, and if it is present, the statistical inferences drawn from the data may be unreliable. In order to validate this, the variance inflation factor (VIF) for multicollinearity was calculated, and was found to be within the interval $(1<\mathrm{VIF}<5)$. After checking the multicollinearity, regression analysis was performed in three steps [49]. The first step was to conduct a regression analysis to determine the direct impact of advertising practises on impulsive purchasing behaviour. In the first step, regression analysis was carried out to assess the direct impact of relationship marketing on the brand resonance of apparel. In the second step, the indirect impact of relationship marketing on brand resonance via eWOM effectiveness was calculated. The results of the regression analysis (Table 6) show that the impact of relationship marketing on brand resonance was significant $(\mathrm{F}=146.967, p=0.000 ; \mathrm{t}=12.123, p=0.000)$ and contributed $23.80 \%\left(R^{2}=0.238\right)$ to brand resonance. The results revealed that the beta values for relationship marketing is 0.501 , and it has a significant effect on brand resonance. Hence, the research hypothesis is accepted, indicating that relationship marketing practices have a significant effect on consumers' brand resonance. 
Table 6. Impact of relationship marketing on brand resonance.

\begin{tabular}{|c|c|c|c|c|c|c|c|}
\hline \multirow{2}{*}{ Model } & \multicolumn{2}{|c|}{$\begin{array}{l}\text { Unstandardized } \\
\text { Coefficients }\end{array}$} & \multirow{2}{*}{$\begin{array}{c}\begin{array}{c}\text { Standardized } \\
\text { Coefficients }\end{array} \\
\text { Beta }\end{array}$} & \multirow[t]{2}{*}{$\mathbf{T}$} & \multirow[t]{2}{*}{ Sig. } & \multicolumn{2}{|c|}{$\begin{array}{c}\text { Collinearity } \\
\text { Statistics }\end{array}$} \\
\hline & B & $\begin{array}{l}\text { Std. } \\
\text { Error }\end{array}$ & & & & Tolerance & VIF \\
\hline \multirow{3}{*}{$\begin{array}{l}\text { (Constant) } \\
\text { Relationship } \\
\text { Marketing }\end{array}$} & 2.287 & 0.152 & & 15.028 & 0.000 & & \\
\hline & 0.501 & 0.041 & 0.488 & 12.123 & 0.000 & 1.00 & 1.00 \\
\hline & \multicolumn{3}{|c|}{$\begin{array}{c}\mathrm{R}=0.488 \\
\mathrm{R}^{2}=0.238 \\
\mathrm{~F}=146.967 \\
p=0.000 \\
\text { of the Estimate }=0.52460\end{array}$} & & & & \\
\hline
\end{tabular}

Dependent variable: brand resonance.

Table 7 indicates that the impact of relationship marketing on eWOM was significant $(\mathrm{F}=170.415, p=0.000 ; \mathrm{t}=13.054, p=0.000)$ and contributed $26.69 \%\left(\mathrm{R}^{2}=0.2669\right)$ to eWOM. The beta value for relationship marketing is 0.534 , and it has a significant effect on eWOM. This leads us to accept the second research hypothesis, i.e., that relationship marketing has a positive influence on eWOM.

Table 7. Impact of relationship marketing on eWOM.

\begin{tabular}{|c|c|c|c|c|c|c|c|}
\hline \multirow{2}{*}{ Model. } & \multicolumn{2}{|c|}{$\begin{array}{l}\text { Unstandardized } \\
\text { Coefficients }\end{array}$} & \multirow{2}{*}{$\begin{array}{c}\begin{array}{c}\text { Standardized } \\
\text { Coefficients }\end{array} \\
\text { Beta }\end{array}$} & \multirow[t]{2}{*}{$\mathbf{T}$} & \multirow[t]{2}{*}{ Sig. } & \multicolumn{2}{|c|}{$\begin{array}{l}\text { Collinearity } \\
\text { Statistics }\end{array}$} \\
\hline & B & $\begin{array}{l}\text { Std. } \\
\text { Error }\end{array}$ & & & & Tolerance & VIF \\
\hline \multirow{3}{*}{$\begin{array}{l}\text { (Constant) } \\
\text { Relationship } \\
\text { Marketing }\end{array}$} & 2.072 & 0.151 & & 13.763 & 0.000 & & \\
\hline & 0.534 & 0.041 & 0.515 & 13.054 & 0.000 & 1.00 & 1.00 \\
\hline & \multicolumn{3}{|c|}{$\begin{array}{c}\mathrm{R}=0.515 \\
\mathrm{R}^{2}=0.266 \\
\mathrm{~F}=170.415 \\
p=0.000 \\
\text { r of the Estimate }=0.519\end{array}$} & & & & \\
\hline
\end{tabular}

Dependent variable: eWOM.

Table 8 indicates the impact of eWOM on brand resonance. It was significant $(\mathrm{F}=10,113.751, p=0.000 ; \mathrm{t}=100.567, p=0.000)$ and contributed $95.6 \%\left(\mathrm{R}^{2}=0.956\right)$ to brand resonance. The results showed that the beta value for eWOM is 0.970 , and it has significant effect on brand resonance.

Table 8. Impact of eWOM on brand resonance.

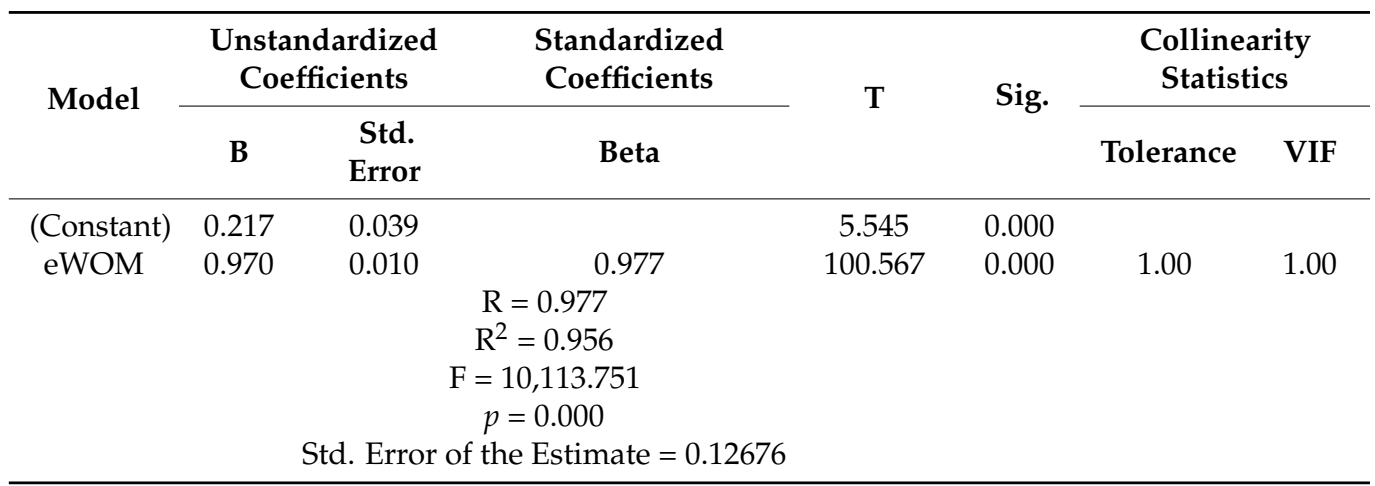




\section{Mediation Effect of eWOM on Relationship Marketing and Brand Resonance}

Table 9A,B shows the outcomes of the Sobel test, Aroian test, and Goodman test that were conducted to judge the result of the mediating variable (eWOM) of a given independent variable (relationship marketing) on a given dependent variable (brand resonance). In general terms, mediation can take place if

Table 9. (A) Influence of the mediating variable using the Sobel test; (B) influence of the mediating variable using the Sobel test.

(A)

\begin{tabular}{cccccc}
\hline & Input & & Test Statistics & Standard Error & $p$-Value \\
\hline A & 0.534 & Sobel test & 12.90854604 & 0.0401269 & 0.000 \\
B & 0.970 & Aroian test & 12.90787228 & 0.040129 & 0.000 \\
$\mathrm{Sa}$ & 0.041 & Goodman test & 12.90921992 & 0.04012481 & 0.000 \\
$\mathrm{Sb}$ & 0.010 & & & & \\
\hline
\end{tabular}

(B)

\begin{tabular}{ccccc}
\hline & Input & & & \\
\hline$t_{\mathrm{a}}$ & 13.054 & Sobel test & 12.94539654 & 0.000 \\
$\mathrm{t}_{\mathrm{b}}$ & 100.567 & Aroian test & 12.9447672 & 0.000 \\
& & Goodman test & 12.94602597 & 0.000 \\
\hline
\end{tabular}

(1) The independent variable notably affects the mediator.

(2) The independent variable notably affects the dependent variable in the absence of the mediator.

(3) The mediator has a major distinct effect on the dependent variable.

(4) The impact of the independent variable on the dependent variable reduces when the mediator is applied to the model.

These principles can be used to determine whether or not a mediation is taking place. The Sobel test indicated that the $p$-value is less than 0.05 , assuming that the two-tailed z-test is higher than 1.96, and therefore that the research hypothesis should be accepted, showing that eWOM mediates the relationship between the relationship marketing and brand resonance of branded apparel.

\section{Discussion of the Results}

The present study examined the impact of relationship marketing on brand resonance and the mediating effect of eWOM on relationship marketing and brand resonance in the context of branded apparel in India. Our research findings indicate that effective eWOM communication mediates the relationship between the relationship marketing and brand resonance of branded apparel among the target consumers. The research outcome indicates that relationship marketing positively influences the brand resonance of consumers towards branded apparels. This conforms to the findings of Divyasre [50], who also confirmed that effective relationship marketing practices are key determinants of brand resonance. Relationship marketing practices such as interpersonal communication with the customer, direct mail to spread information to the customer, a tangible rewards system, preferential treatment to customers, customization methods, individualized attention, and effective eWOM influence behavioral loyalty. Affective attachment, a sense of continuity, and active engagement result in high brand resonance. Hence, the study concludes that perceived relationship marketing activities are an efficient and effective tool for developing a strong relationship with customers, and building the high brand resonance of branded apparels. We conclude that effective relationship marketing activities can enhance brand trust and loyalty by augmenting the relationship with the branded apparel.

The results of the testing of the second hypothesis showed that relationship marketing positively influences eWOM. Moreover, the assumption of the mediating effect of eWOM 
on the relationship between relationship marketing and brand resonance was found to be valid. Compared to the product quality, eWOM is seen as a distinctive marketing strategy undertaken by organizations marketing branded apparel. It is believed that eWOM plays a dynamic role in building consumer trust and consumer loyalty, and influences them to pay a premium for the brand. Besides information and attention, eWOM attempts to make appropriate changes in their attitudes and beliefs, thus leading to high brand loyalty and customer retention. In this modern age of marketing, brands stand for greatness if customers are able to identify them in the marketplace. "Strong brands have duality; they appeal to both the head and the heart". Modern customers, especially young citizens, regard relationship marketing as a more reliable source of information about their brands than traditional instruments of marketing communications. In view of this, relationship marketing activities like effective brand promotion, information facilitation and customized brand communications strategies shape the eWOM's effectiveness. Thus, it can be concluded that relationship marketing practices provide a strategic advantage to contemporary business organizations in the market place in order for them to compete with their competitors in the differentiation of their offerings. Marketers also understand the fact that relationship marketing in association with eWOM has immense reach, high popularity, high credibility and is cost effective. They must use constant brand communication and engagement strategies, share useful information about brands and market trends, and develop a feeling of community and social bonds for encouraging brand loyalty and brand attachment that in turn enhance brand resonance.

Researchers, therefore, recommend that marketing practitioners or brand managers concentrate on relationship marketing with extensive eWOM to improve the brand resonance of the branded apparel preference of modern customers. Keeping these in mind, the implications of the research work will help brand managers, marketers and industryplayers to exploit eWOM and relationship marketing practices to increase the brand preferences and market-share of their brands. Brand managers and marketers must deliver effective services to customers, offer social status, design relationship-marketing practices, develop elite brand positioning, and concentrate on changing the preferences of fashionconscious consumers to create brand resonance. In addition, they must understand the effective brand information search, brand comparison, online brand communities, updates on industry trends, and personalized brand communication contents specific to each media platform as well as eWOM to build a better relationship with the brand.

\section{Implication}

The results of the present study revealed the importance of eWOM strategies for strengthening the influence of the relationship marketing and brand resonance of branded apparel products. These venues of eWOM require managerial attention for proper brand management and to reduce the asymmetry of information that consumers receive about branded apparel products. The practical implication of this study is that it provides marketing professionals with a frame of reference to understand the power of the relationship between eWOM, relationship management, brand resonance, and share the marketing and advertising news published by media outlets on social networking sites (SNSs). In this regard, businesses should recognize the importance of improving their relationships with the media, as unfavorable news may have a detrimental impact on the public perception of a company's brand. In this sense, organisations which are really concerned with boosting the long-term viability of their brand should take note. Similarly, corporations may use extra public relations methods to boost brand resonance and market sustainability problems, such as business events, sponsorships or partnerships, or even trade fairs, workshops, and press tours for journalists. Similarly, corporations may monitor and analyze eWOM issues on social media in order to learn how customers perceive a company or its brand. As a result, businesses may examine customer expectations and incorporate them into future relationship marketing strategies. In this sense, before using public relations techniques, 
businesses must ensure that they represent and convey their brand honestly in order to avoid misunderstandings.

From the perspective of media organizations, these organizations should be mindful of the potential of eWOM to convey brand concerns to users. Our findings will be useful in developing strategies to improve not just the use of their social platforms, but also their visibility among users. As a result, by raising the degree of information value supplied in such postings, consumers may encourage users to share and comment on brand-related news released on SNSs. Following that, media sources (e.g., newspapers) should broadcast brand-related news that is relevant, accurate and complete in order to improve the possibility of eWOM intents, hence boosting their degree of exposure in the branding context as well as users' awareness about this information.

From the perspectives of SNS companies, as they monitor the information they receive, they must be aware of how users seek information and how they utilise this data to create opinions. They will be able to target individuals more effectively as a result of this. This study lays the path for future research and provides practical recommendations for firms to investigate various aspects of eWOM and relationship marketing in order to improve the brand resonance of branded clothing goods. This research also leads to an investigation of several aspects that determine the distinctiveness of brand resonance. The study's findings may be valuable to local marketers and producers by raising their awareness of the psychological need of the customer in the brand. This study provides a broader perspective and detailed knowledge on the eWOM and consumer brand relationship that are strongly demanded, and it enhances brand resonance with a view to making higher profits.

\section{Limitations and Future Research Scope}

There are some limitations to the current study that must be addressed. The finding's generalizability is a limitation of this work because it is based on data collected from specific responses from Indian consumers via an online survey developed on Google forms. Another limitation of the study is the removal of items during the pilot phase of the study. Those dropped items may have behaved differently in another study sample when using the brand. The third limitation appears to result from the sample's cross-sectional nature. Furthermore, no definitive conclusions can be drawn about the causal relationship. These tests should be supplemented with a variety of methods that can increase the significance of the findings. Longitudinal study designs are needed to investigate the proposed model in order to achieve a more acceptable causality. The fourth limitation of the study is that all of the results are based on qualitative and self-reporting data, which cause the traditional variance approach findings to be distorted. Although the statistical analysis revealed no significant concern about a specific system's variance, the potential effects of variance in the standard method may influence the findings.

In order to avoid this problem in the future, studies should collect data from multiple sources. The relevance of the results can be increased by drawing them from a larger population. Furthermore, in future research, it is critical to investigate additional factors of relationship marketing and electronic word-of-mouth communication for building brand resonance. In the long run, it will be interesting to test and retest the current study of the brand resonance measurement scale in order to improve its generalizability. It will also be interesting to apply this brand resonance scale and test the brand resonance model with different brand categories and market segments. The current study has the potential to be expanded in order to test the present scale of brand resonance with mediation or moderation model analysis. Hence, future studies should not be limited to the performance of the analysis of brand resonance with different products or brand categories. 


\section{Conclusions}

Complex business environments, rising demand for branded apparel, and fierce competition have compelled marketers to develop innovative marketing strategies in order to attract and retain modern consumers. The current study looked at the relationship between relationship marketing, eWOM and brand resonance in the context of branded apparel in India. These findings suggested that organisations and brand managers should focus more on the effective use of relationship marketing for brand positioning, facilitating information sharing, customer engagement, and developing meaningful customer relationships, which show a tendency toward business growth and sustainability. The novelty of this research, per the research outcome, is that continuous innovation in relationship marketing in association with eWOM will definitely satisfy brand resonance and its novelty needs. The valued relationship-marketing activities and effective eWOM will help organizations to face the competition successfully and build strong brand relationships. Marketers and brand managers can take advantage of relationship marketing to interact with customers, develop meaningful relationships and achieve brand resonance. In the case of developing economies like India, where modern consumers prefer lifestyle products for self-portrayal and status, it is advisable that organizations and brand managers must concentrate on brand building through eWOM and relationship marketing strategies for the creation of brand resonance. As a field for future studies, examining this work in other cultures and industries or by other methods could yield comparable results.

Author Contributions: Conceptualization, Methodology and Writing-original draft, S.H. and N.N.H.; Writing-review \& editing, S.H., N.N.H. and M.A.K.; Formal analysis, S.H.; Supervision, Validation, N.N.H.; Funding acquisition, M.A.K. All authors have read and agreed to the published version of the manuscript.

Funding: This research received no external funding.

Institutional Review Board Statement: Not applicable.

Informed Consent Statement: Not applicable.

Data Availability Statement: The data presented in this study are available on request from the first author.

Conflicts of Interest: The authors declare no conflict of interest.

\section{References}

1. Kala, D.; Bagri, S. Designing the strategy map for hotels with key performance indicators of balanced scorecard using DEMATEL technique. Int. J. Bus. Excell. 2016, 10, 240-263. [CrossRef]

2. Amoako, G.K. Relationship marketing, orientation, brand equity and firm value: The mediating role of customer value-An emerging market perspective. J. Relatsh. Mark. 2019, 18, 280-308. [CrossRef]

3. Backhaus, K.; Steiner, M.; Lügger, K. To invest, or not to invest, in brands? Drivers of brand relevance in B2B markets. Ind. Mark. Manag. 2011, 40, 1082-1092. [CrossRef]

4. Grönroos, C. A service perspective on business relationships: The value creation, interaction and marketing interface. Ind. Mark. Manag. 2011, 40, 240-247. [CrossRef]

5. Aghaei, M.; Vahedi, E.; Kahreh, M.S.; Pirooz, M. An examination of the relationship between services marketing mix and brand equity dimensions. Procedia Soc. Behav. Sci. 2014, 109, 865-869. [CrossRef]

6. Erdem, T.; Swait, J. Brand equity as a signaling phenomenon. J. Consum. Psychol. 1998, 7, 131-157. [CrossRef]

7. RC, R.C.L.; Hadd, J. Building a Brand in Higher Education: Why business practices-particularly brand strategies-are becoming essential in today's universities. Galiup Manag. J. 2007, 12, 1-6.

8. Chen, L.-H. Internationalization or international marketing? Two frameworks for understanding international students' choice of Canadian universities. J. Mark. High. Educ. 2008, 18, 1-33. [CrossRef]

9. Keller, K.L. Building Customer-Based Brand Equity: A Blueprint for Creating Strong Brands; Marketing Science Institute: Cambridge, MA, USA, 2001.

10. Rindfleisch, A.; Wong, N.; Burroughs, E. Seeking certainty via brands: An examination of materialism and brand resonance. In Proceedings of the ACR 2006 North American Conference runs, Orlando, FL, USA, 27 September-1 October 2006; pp. 1-44.

11. Keller, K.L. Building strong brands in a modern marketing communications environment. J. Mark. Commun. 2009, 15, 139-155. [CrossRef] 
12. Khanna, M.; Jacob, I.; Chopra, A. Promoting business school brands through alumni (past customers)-analyzing factors influencing their brand resonance. J. Promot. Manag. 2019, 25, 337-353. [CrossRef]

13. Bapat, D.; Thanigan, J. Exploring relationship among brand experience dimensions, brand evaluation and brand loyalty. Glob. Bus. Rev. 2016, 17, 1357-1372. [CrossRef]

14. Becheur, I.; Bayarassou, O.; Ghrib, H. Beyond brand personality: Building consumer-brand emotional relationship. Glob. Bus. Rev. 2017, 18, S128-S144. [CrossRef]

15. Raut, U.R.; Brito, P.Q. An Analysis of Brand Relationship with the Perceptive of Customer Based Brand Equity Pyramid; School of Economics and Management, University of Porto: Porto, Portugal, 2014; Volume 26.

16. Rindfleisch, A.; Burroughs, J.E.; Wong, N. The safety of objects: Materialism, existential insecurity, and brand connection. J. Consum. Res. 2009, 36, 1-16. [CrossRef]

17. Keller, K.L. Understanding the richness of brand relationships: Research dialogue on brands as intentional agents. J. Consum. Psychol. 2012, 22, 186-190. [CrossRef]

18. Kala, D.; Chaubey, D. The effect of eWOM communication on brand image and purchase intention towards lifestyle products in India. Int. J. Serv. Econ. Manag. 2018, 9, 143-157.

19. Mohammadhossein, N.; Zakaria, N.H. CRM benefits for customers: Literature review (2005-2012). Int. J. Eng. Res. Appl. 2012, 2, 1578-1586.

20. Tsai, S.P. Strategic relationship management and service brand marketing. Eur. J. Mark. 2011, 45, 1194-1213. [CrossRef]

21. Ndubisi, N.O.; Wah, C.K. Factorial and discriminant analyses of the underpinnings of relationship marketing and customer satisfaction. Int. J. Bank Mark. 2005. [CrossRef]

22. Firdaus, A.; Kanyan, A. Managing relationship marketing in the food service industry. Mark. Intell. Plan. 2014, 32, 293-310. [CrossRef]

23. Keller, K.L.; Parameswaran, M.; Jacob, I. Strategic Brand Management: Building, Measuring, and Managing Brand Equity; Pearson Education India: Noida, India, 2011.

24. Hennig-Thurau, T.; Gwinner, K.P.; Walsh, G.; Gremler, D.D. Electronic word-of-mouth via consumer-opinion platforms: What motivates consumers to articulate themselves on the internet? J. Interact. Mark. 2004, 18, 38-52. [CrossRef]

25. Bickart, B.; Schindler, R.M. Internet forums as influential sources of consumer information. J. Interact. Mark. 2001, 15, 31-40. [CrossRef]

26. Tsimonis, G.; Dimitriadis, S. Brand strategies in social media. Mark. Intell. Plan. 2014, 32, 328-344. [CrossRef]

27. Habib, S.; Hamadneh, N.N.; Alsubie, A. Modeling Advertising Practices for Product Involvement and Consumer Impulsivity in Branded Apparel: A Case Study of Indian Consumers. Sustainability 2021, 13, 2309. [CrossRef]

28. Wang, X.; Yu, C.; Wei, Y. Social media peer communication and impacts on purchase intentions: A consumer socialization framework. J. Interact. Mark. 2012, 26, 198-208. [CrossRef]

29. Torlak, O.; Ozkara, B.Y.; Tiltay, M.A.; Cengiz, H.; Dulger, M.F. The effect of electronic word of mouth on brand image and purchase intention: An application concerning cell phone brands for youth consumers in Turkey. J. Mark. Dev. Compet. 2014, 8, 61.

30. Jalilvand, M.R.; Samiei, N. The effect of electronic word of mouth on brand image and purchase intention: An empirical study in the automobile industry in Iran. Mark. Intell. Plan. 2012, 30, 460-476. [CrossRef]

31. Burmann, C. A Call for 'User-Generated Branding'; Springer: Berlin/Heidelberg, Germany, 2010.

32. Habibi, M.R.; Laroche, M.; Richard, M.-O. The roles of brand community and community engagement in building brand trust on social media. Comput. Hum. Behav. 2014, 37, 152-161. [CrossRef]

33. Levy, S.; Hino, H. Emotional brand attachment: A factor in customer-bank relationships. Int. J. Bank Mark. 2016, 34, 136-150. [CrossRef]

34. Thomson, M.; MacInnis, D.J.; Park, C.W. The ties that bind: Measuring the strength of consumers' emotional attachments to brands. J. Consum. Psychol. 2005, 15, 77-91. [CrossRef]

35. Park, C.W.; MacInnis, D.J.; Priester, J.; Eisingerich, A.B.; Iacobucci, D. Brand attachment and brand attitude strength: Conceptual and empirical differentiation of two critical brand equity drivers. J. Mark. 2010, 74, 1-17. [CrossRef]

36. Gómez-Suárez, M.; Veloso, M. Brand experience and brand attachment as drivers of WOM in hospitality. Span. J. Mark. Esic 2020, 24, 231-246. [CrossRef]

37. Laroche, M.; Habibi, M.R.; Richard, M.-O. To be or not to be in social media: How brand loyalty is affected by social media? Int. J. Inf. Manag. 2013, 33, 76-82. [CrossRef]

38. Qiao, L.; Song, M.; Wang, N. Virtual brand community experience, identification, and electronic word-of-mouth. J. Comput. Inf. Syst. 2019, 1-14. [CrossRef]

39. Chu, S.-C.; Kim, Y. Determinants of consumer engagement in electronic word-of-mouth (eWOM) in social networking sites. Int. J. Advert. 2011, 30, 47-75. [CrossRef]

40. Al-Htibat, A.; Garanti, Z. Impact of interactive eReferral on tourists behavioral intentions. Mark. Intell. Plan. 2019, 37, 527-541. [CrossRef]

41. Naumann, K.; Bowden, J.; Gabbott, M. Expanding customer engagement: The role of negative engagement, dual valences and contexts. Eur. J. Mark. 2020, 54, 1469-1499. [CrossRef]

42. Leventhal, R.C.; Hollebeek, L.D.; Chen, T. Exploring positively-versus negatively-valenced brand engagement: A conceptual model. J. Prod. Brand Manag. 2014, 23, 62-74. 
43. Al-Dmour, H.; Aloqaily, A.; Al-Qaimari, R.; Al-Hassan, M. The effect of the electronic word of mouth on purchase intention via the brand image as a mediating factor: An empirical study. Int. J. Netw. Virtual Organ. 2021, 24, 182-199. [CrossRef]

44. Jones, M.A.; Reynolds, K.E.; Arnold, M.J.; Gabler, C.B.; Gillison, S.T.; Landers, V.M. Exploring consumers' attitude towards relationship marketing. J. Serv. Mark. 2015, 29, 188-199. [CrossRef]

45. Huang, R.; Lee, S.H.; Kim, H.; Evans, L. The impact of brand experiences on brand resonance in multi-channel fashion retailing. J. Res. Interact. Mark. 2015, 9, 129-147. [CrossRef]

46. Çifci, S.; Ekinci, Y.; Whyatt, G.; Japutra, A.; Molinillo, S.; Siala, H. A cross validation of Consumer-Based Brand Equity models: Driving customer equity in retail brands. J. Bus. Res. 2016, 69, 3740-3747. [CrossRef]

47. Habib, S.; Hamadneh, N.N.; Masadeh, R. Computation analysis of brand experience dimensions: Indian online food delivery platforms. Comput. Mater. Contin. 2021, 67. [CrossRef]

48. Ong, C.H.; Lee, H.W.; Ramayah, T. Impact of brand experience on loyalty. J. Hosp. Mark. Manag. 2018, 27, 755-774. [CrossRef]

49. Dospinescu, O.; Dospinescu, N. Workaholism in IT: An Analysis of the Influence Factors. Adm. Sci. 2020, 10, 96. [CrossRef]

50. Divyasre, V. Brand Resonance: Concept and Influence of Relationship Marketing Dimensions with Reference to Online Shopping Portals. Indian J. Public Health Res. Dev. 2019, 10, 118-122. [CrossRef] 